\title{
Research on Analysis and Forecast of Truck Market in China
}

\author{
Xingfeng Liu, Zhongxia Zheng and Zhou Tiansong \\ 1, 2, 3 School of Management, Wuhan University of Technology, P. R. China, 430070 \\ 249763651@qq.coml
}

\begin{abstract}
For the modern enterprises, it is significant to develop production according to the market demand, and there is no exception to the auto companies. The article tries to establish a statistical model to predict the number of the truck ownership and provide references for truck manufacturers to make production plans. Thus, the situation of China's truck market is introduced; the analysis of the overall trend of changes of the China's truck market holdings is made; and the concept and classification of forecasting methods are introduced. For the prediction of the future of China's truck market, researchers use quantitative and qualitative analysis, combining the advantages of both methods. Firstly, researchers find the relevant factors that affect laden car ownership through qualitative analysis. Secondly, on the further quantitative analysis, researchers determine main factors of the mileage of highways, infrastructure investment in fixed assets and amount of social consumption expenditure, etc. Thirdly, by the use of the above analysis results, multivariate regression model models are made, which is also the key part of the article. The last but not the least, analysis and comparison of the advantages and disadvantages of model are made eventually.
\end{abstract}

Keywords-Truck; Auto Market Prediction; Model

\section{OVERVIE W OF TRUCK MARKET}

The automotive industry is a pillar industry in China, having more characteristics of the pillar industry in the "Eleventh Five-Year Plan". According to the analysis of Deputy Minister of Industrial Economics Research Department of the State Council Development Research Center, China's high growth industries have important features of economic growth in this round. Among the high growth industry herd, the consumption structure upgrading industries of automotive and housing, together with steel industries, form high-growth industries.

According to economic trend of "Eleventh Five-Year Plan" period, it was predicted that China's economy would maintain rapid growth, and the GDP growth rate would be around $8 \%$. If it was calculated in accordance with constant price, the total GDP of China in 2010 reached \$ 2.4 trillion. From 2010 to 2020, the growth rate is slower, with an average annual growth rate of $7 \%$. In 2020 , the total GDP will be $\$ 4.8$ trillion. In 2010 , due to the rapid development of automobile industry, automobile proportion of GDP was $1.4 \%$. In 2004 , it was $1.6 \%$. In 2010 , added value of the automotive industry to GDP ratio was more than $2 \%-2.5 \%$. From the total amount, the features of automobile industry as a pillar industry will be more apparent.

As one of the car categories, truck market holdings account for a proportion of about 40 percent of the entire car market. It has become an important part of China's pillar industries. From Fig. 1, researchers can see the growth rate of ownership of the Chinese truck market. It shows that except negative growth of truck market holdings in 1995, the growth rate was more than $4 \%$ in other years. In 1991, there was a rapid growth of $11 \%$. In 2009, from the truck market holdings and the line column chart of grass domestic production. It can be seen that China's truck market holdings and domestic GDP growth is roughly in the same trend. With the increasing growth of country's GDP, China's truck market holdings have also increased steadily from less than 4 million in 1989 to nearly 12 million in 2012, with an increase of more than 2 times. 


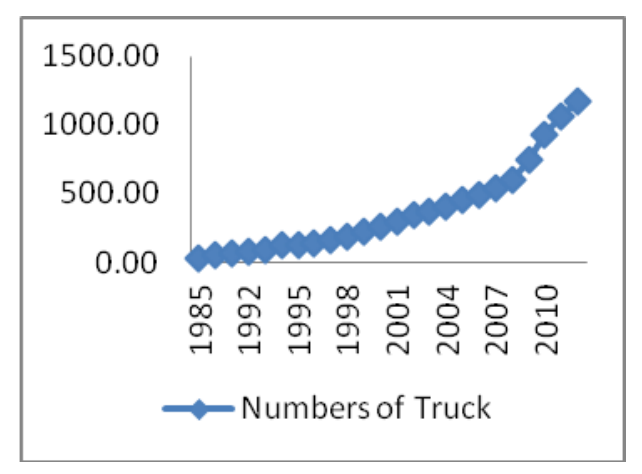

Figure 1. Chinese Truck Market

\section{TRUCK MARKET RESEARCH StATUS AT HoME AND} ABROAD

In China, during the planned economy period, the production plans of manufacturing companies were formulated by the country. The companies did not need to consider the relationship between market demand and supply. But now, in the market economy, manufacturing companies make their production plans by themselves and this requires manufacturers to understand the market trends and market demands [1]. Therefore, it is very important to forecast the market demand [2]. For this reason, over the past decade, articles of market demand forecasting have been increasing, and the measures of predicting are richer and deeper as well[3].

In recent years, automotive industry are becoming a pillar industry of the national economy, so experts and scholars have attached great importance to it[4-8]. As the important part of the automotive industry, trucks have become the focus. There are a number of publications of articles on the automotive market forecasting every year, many of which are analysis and forecast of the following two major truck subdivision markets, i.e. heavy trucks and medium trucks[9-12]. Due to limited space, researchers will not give specific analysis of the subdivision markets of trucks here.

In summary, research methods used in articles of automotive market analysis and forecasting can be divided into four levels:

The first level is qualitative analysis. As for truck demand forecasts, it is pointed out in articles that the situation of the national economy, investment in fixed assets, bank credit scale, road and urban construction and other economic and non-economic factors, affect the automotive market because they are directly or indirectly under impact of automotive industry and related industries [13-16]. The basic size and characteristics of truck market operation are formed under the influence of non-economic factors of economic policy and macroeconomic environment[17]. Prevailing macro-economic policies and non-economic factors are analyzed; forecasting conclusions are made thereafter [18]. Actually, approaches in the overwhelming majority of articles about the car market forecast, are qualitative analysis.

The second level is analysis with the use of growth rate year on year [19-20]. Some experts calculated the growth rate of the previous period of the year, and analyzed several factors to promote the development of light-duty vehicles. These authors have concluded that the growth rate should have an increase and give the forecast value eventually. However, this method is relatively rare in prediction.

The third level is the establishment of a single econometric model. Senior analysts said the domestic truck industry has two models. One is GDP and elastic model of market sales, and the other is an elastic model of the scale of investment in fixed assets and truck needs [21]. In addition to the elastic model, scholars have made use of other econometric models for automotive market analysis and forecasting [22]. Among all of these, time series models are established in trend extrapolation, nonlinear models of car ownership and the GNP are built in international analogy. Hence, the introduction of the model has greatly improved the accuracy of forecasts.

The fourth level is utilization of several econometric models [23-24]. These models include multiple linear regression model, trend extrapolation model and time sequence. These methods of forecast are more accurate than single econometric model because market trends and factors that affect the market changes are all taken into account.

\section{Model SELECTION OF TRUCK MARKET ForeCAST}

In general, all-time series are affected by historical information, regardless of linear or nonlinear influence. Forecasting of truck market holdings is also a time-series problem, and the future market holdings would be influenced by the previous market holdings. Therefore, 
forecasts can be made through establishment of the time series extrapolation model.

Meanwhile, laden car ownership will also be influenced by a lot of other factors, such as highway mileage, the number of infrastructure investment, the amount of social spending, etc., so they can be considered to analyze the influence of these factors to automobile ownership in the market. On the basis of these factors, regression models are made to predict future market holdings. Since the factors that influence truck ownership are various, and simple multivariate regression model only cover part of the factors. Researchers consider making correlation analysis on these factors first, and then selecting some major factors with high correlation to establish multivariate regression models.

After the establishment of the model, a series of tests are needed to determine whether the model is reasonable to be in accordance with relationship between variables. Having examined the model, researchers can use them for forecasting. In general, the model needs to be tested in three areas: economic significance testing, statistical testing and econometric testing.

First researchers need to examine whether the model meets the economic significance, whether the sign and magnitude obtained by the test parameter estimation are reasonable, and whether the model is in accordance with people's expectations based on experience and economic theory. If models do not match, researchers have to find the cause and take the necessary corrective measures to re-establish the model.

Statistical tests include goodness of fit test, significance of regression equation test ( $\mathrm{F}$ test) and variables significant test ( $\mathrm{t}$ test). Goodness of fit test is to test degree of correlation among all independent variables and the dependent variable. In other words, it is the test of the fit of regression equations to sample observations. Significance test ( $\mathrm{f}$ test) is to make inferences on the fact whether the linear relationship between variables and explanatory variables in the model is generally significant or not. Variable significance test ( $\mathrm{t}$ test) is to test whether the impact of each explanatory variable on the dependent variable is significant or not.

Econometric testing is the most important test. It is the random disturbance serial correlation test, multicollinearity and heteroscedasticity test. Meanings of autocorrelation are correlations of the relevant members of the observation of a sequence either in time (such as in time-series data) or space (such as in the cross-sectional data). When the econometric models appear to be self-correlation, if the estimated model parameters of method OLS are still used, the OLS estimation is still unbiased estimation without validity. OLS estimation is generally underestimated, leading test reliability to be reduced.

If there is a correlation between two or more explanatory variables, it is called multicollinearity. Once multicollinearity appears in the econometric models, if the ordinary least squares estimation of model parameters are still used, OLS estimators are still the best linear unbiased estimator, but it is not "perfect", especially not giving really useful information on statistical inference

In terms of forecasting, one of the major concern is prediction accuracy. To ensure the prediction accuracy, it is necessary to choose effective predictive models. In the prediction model, there is no predicting model which may always be superior to other models in terms of efficacy in all aspects. In this sense, it is impossible to find the "best" model. Relatively speaking, researchers seek "better” or "good" model, and here "good" or "better" search is for relatively certain evaluation criteria.

\section{FACTORS OF TRUCK MARKET ANALYSIS}

\section{A. Background of Truck Development}

\section{1) Macroeconomic Environment}

National Development and Reform Commission had estimated that in 2012 the annual fixed asset investment and retail sales had grown $25 \%$ and $13 \%$ respectively. It is said by Macroeconomic Research Institute of National Development and Reform Commission that in 2013 the total size of fixed asset investment had grown by about $20 \%$, and the retail sales had grown $12 \%$ to $13 \%$. In 2014 , China's consumer price index (CPI) growth rate continued to fall, the government will work to expand domestic demand and deal with the problem of overproduction in many industries.

Furthermore, the central economic work conference basically finalized the main theme of the monetary policy: to maintain the continuity and stability of policy and continue to implement a prudent monetary policy. 
According to China's social and economic systems analysis study, in "Twelfth Five-Year Plan", the nation will continue to implement a proactive fiscal policy, accelerating the western development, revitalization of northeast old industrial base, and increasing investment in infrastructure. Thus these will bring about demand growth in the areas like hydropower, water, oil, roads, railways, real estate development, urban transport and environmental projects. They will also undoubtedly help the development of the automotive market.

2) Industrial Policy

Industrial policy is an advanced form of intervention and participation of the state in the economy. It is designed to focus on a more complete and systematic policy system throughout the country from the global industrial development, rather than just partial policies on both industries.

In recent years, with the establishment of fast-growing auto market, the pillar industry status of cars is established. The government has significantly accelerated the automotive industry research and regulatory policy formulation. In June 2004 in particular, after the new "auto industry policy" was promulgated, supporting policies had been put for the policy. In 2005, several policies with wide public concern, such as "Import Management Approach of Auto Parts of Complete Vehicle Features, "Car Brand Sales Management Approach", "Automotive Trade Policy", "Management Approach of Used Car Circulation" and imported cars landing contraband policies had been formally implemented. In addition, the Ministry of Transportation issued a "Trial Weight Turnpike Toll Guidance" to regulate and guide the work on the weight charges. These charging methods have changed the original measures, in which collection tolls practices were based on the quality of the vehicle loading and vehicle classification and the government had collected tolls based on field measurements of the total weight of goods vehicles weighing. The main policy measures include: Re-approved Weight Charges after a Trial of New Tolls Basic Rate; Reasonable Toll Charges Calculation in Accordance with the Total Weight of Goods Vehicles; Unified and Clear Standards of the Road Carrying Capacity.
These policies and measures have made the norm from the production and circulation of the automotive industry. They have some impacts on automobile market in short-term. But in the long term, it has strengthened the overall competitiveness of China's automobile industry and promoted the healthy development of the car market. With the implementation of fuel tax, the adverse effects suffered by ordinary trucks are enormous. For instance, profitability has declined and fuel duty has huge impacts on Chinese truck market.

\section{3) Governance on Overload}

According to the Vice Minister of the National Leading Group on Governance super job, deputy head of the National Governance ultra-Director, Ministry of Communications, the national governance over the work of institutions and funds would not be diminished in 2014 .

Strengthening the law enforcement, improving the monitoring network and establishing long-term mechanism have highlighted the source of governance to take severe penalties on illegal overloading of vehicles. Experts pointed out in articles that with the further implementation, transportation market tended to be more and more standard and healthier.

Rapid development of China's economy, increasing freight volume and transport rule on overload have resulted in a relative decrease in transport vehicles, and these factors are inevitable requests for additional freight vehicles to meet the demand for freight transport.

Full implementation of overload has resulted in a series of effects. On one hand, truck loading capacity is limited, and this restricts the sale. On the other hand, reducing the truck loading would prolong the life of the trucks, and this has resulted in decreased demand update. Of course, the strict implementation of overload has urged some users to purchase trucks which are in line with current regulatory requirements and multi-laden models. Thus, all these have stimulated demands for these models.

\section{4) Potential Demand}

Rapid economic development will inevitably bring the transfer of more products, production of goods and raw materials, promoting the development of the transport industry. Compared with transportations of trains, ships and aircraft, the automobiles are characterized by "door to door" service, which is unmatched by other modes of transportation. In the meanwhile, the cost is relatively low. 
Automobiles play an important role in transportation industry and they will continue to increase their status in economic life.

Road freight has been in the top $90 \%$ of the total social freight transport of goods in various transport ways in developed countries. China accounts for about 70\%. In some countries, road freight turnover accounts for $50 \%$ of whole social transported cargo, but only about $13 \%$ in China. All these figures prove that our truck market still has the potential of growth.

Moreover, urban construction in China requires a lot of special-purpose vehicles, and urban life service vehicles will be a substantial increase. In oil mining site, there is a heavy demand of a lot of large water specialized vehicles, which are favorable factors in truck market development. But at the same time, China has furthered strengthening in the safety management of coal industry by closing many small coal mines. And these undoubtedly have caused inhibition of potential demand.

In "Highway and Waterway Transportation Planning and Long-term Scientific and Technological Development (2006-2020)", it is pointed out that by 2020, the total road network will reach 3 million kilometers, in which highway mileage is $85,000 \mathrm{~km}$. To some extent, further construction of the road network will stimulate the development of China's truck market.

\section{B. Influencing Factors}

In the market economy, the truck market holdings are influenced and formed by a number of factors. Researchers have analyzed above, from a qualitative point of view. For the following, researchers would use quantitative methods to analyze the relevant factors, and identify how strong the correlation is.

\section{1) Method of Correlation Analysis}

Correlation analysis makes research on the degree of linear relationship between two variables. The relationship between two variables is linear or non-linear, so the method of the corresponding correlation analysis is different. Normally distributed data can generally be used in Pearson correlation analysis method. However, when the data is not normally distributed, researchers must adopt correlation analysis methods of Spearman and Kendall, both of these are non-parametric correlation analysis.

\section{2) Correlation Analysis}

a) Data Selection. Researchers have just analyzed some factors that affect ownership in truck markets from the perspective of the qualitative. Now researchers want to analyze their impacts of factors from quantitative aspect. First, researchers must find the relevant data. Referring “China Statistical Yearbook 2013", researchers have selected sectional data from three categories in national accounting, fixed asset investment, transport and telecommunications in 31 provinces. See the Selected indicators in Table 1 below.

TABLE I. PRELIMINARILY SELECTED INDICATORS

\begin{tabular}{|c|c|}
\hline \multicolumn{2}{|c|}{ y laden car ownership $(10,000)$} \\
\hline x1 kilometers (km) & $\begin{array}{l}\text { x18 wholesale and retail } \\
\text { capital investment (hundred } \\
\text { million RMB) }\end{array}$ \\
\hline x2 Level Road (km) & $\begin{array}{l}\text { x19 water, environment, } \\
\text { public facilities, } \\
\text { infrastructure investment } \\
\text { (hundred million RMB) }\end{array}$ \\
\hline x3 High Road (km) & $\begin{array}{l}\text { x20 new fixed assets of } \\
\text { basic building (hundred } \\
\text { million RMB) }\end{array}$ \\
\hline x4 cargo (tons) & $\begin{array}{l}\text { x21 new fixed assets of } \\
\text { mining infrastructure } \\
\text { (hundred million RMB) }\end{array}$ \\
\hline $\begin{array}{l}\text { x5 turnover (one hundred } \\
\text { million tons - kilometers) }\end{array}$ & $\begin{array}{l}\text { x22 new fixed assets of } \\
\text { basic building of } \\
\text { manufacturing (hundred } \\
\text { million RMB) }\end{array}$ \\
\hline $\begin{array}{l}\text { x6 gross regional product } \\
\text { (hundred million } \mathrm{RMB} \text { ) }\end{array}$ & $\begin{array}{l}\text { x23 new fixed assets of } \\
\text { basic construction of } \\
\text { electricity, gas and water } \\
\text { production and supply } \\
\text { (hundred million RMB) }\end{array}$ \\
\hline $\begin{array}{l}\text { x7 gross regional product of } \\
\text { primary industry (hundred } \\
\text { million RMB) }\end{array}$ & $\begin{array}{l}\text { x24 new fixed assets of } \\
\text { infrastructure construction } \\
\text { (hundred million RMB) }\end{array}$ \\
\hline $\begin{array}{l}\text { x8 gross regional product of } \\
\text { secondary industry (hundred } \\
\text { million } \mathrm{RMB} \text { ) }\end{array}$ & $\begin{array}{l}\text { x25 transportation, storage } \\
\text { and postal services } \\
\text { infrastructure of new fixed } \\
\text { assets (hundred million } \\
\text { RMB) }\end{array}$ \\
\hline
\end{tabular}




\begin{tabular}{|c|c|}
\hline $\begin{array}{l}\text { x9 gross regional product of } \\
\text { tertiary industry } t \text { (hundred } \\
\text { million } \mathrm{RMB} \text { ) }\end{array}$ & $\begin{array}{l}\text { x26 wholesale and retail } \\
\text { infrastructure of new fixed } \\
\text { assets (billion } \mathrm{RMB} \text { ) }\end{array}$ \\
\hline $\begin{array}{l}\text { x10 final consumption } \\
\text { (hundred million RMB) }\end{array}$ & $\begin{array}{l}\text { x27 new fixed assets of } \\
\text { basic construction of water, } \\
\text { environment and public } \\
\text { facilities management } \\
\text { (hundred million RMB) }\end{array}$ \\
\hline $\begin{array}{l}\text { x11 resident consumption } \\
\text { (hundred million } \mathrm{RMB} \text { ) }\end{array}$ & $\begin{array}{l}\text { x } 28 \text { The total retail sales of } \\
\text { social consumption goods } \\
\text { (hundred million RMB) }\end{array}$ \\
\hline $\begin{array}{l}\text { x12 } \\
\text { consumption } \\
\text { million RMB) }\end{array}$ & $\begin{array}{l}\text { x29 Municipal total retail } \\
\text { sales of consumption goods } \\
\text { City (hundred million } \\
\text { RMB) }\end{array}$ \\
\hline $\begin{array}{l}\text { x13 infrastructure } \\
\text { investment (hundred million } \\
\text { RMB) }\end{array}$ & $\begin{array}{l}\text { x30 Prefectural total retail } \\
\text { sales of consumption goods } \\
\text { (hundred million RMB) }\end{array}$ \\
\hline $\begin{array}{l}\text { x14 mining infrastructure } \\
\text { investment (hundred million } \\
\text { RMB) }\end{array}$ & $\begin{array}{l}\text { x31(subdivisions of the } \\
\text { counties) The total retail } \\
\text { sales of consumption goods } \\
\text { (hundred million RMB) }\end{array}$ \\
\hline $\begin{array}{l}\text { x15 manufacturing capital } \\
\text { investment (hundred million } \\
\text { RMB) }\end{array}$ & $\begin{array}{l}\text { x32 wholesale and retail } \\
\text { trade of consumer goods } \\
\text { retail(hundred million } \\
\text { RMB) }\end{array}$ \\
\hline $\begin{array}{l}\text { x16 infrastructure } \\
\text { construction investment } \\
\text { (hundred million RMB) }\end{array}$ & x33 Number of Prefectures \\
\hline $\begin{array}{l}\text { x17 transportation, storage } \\
\text { and postal services (ten } \\
\text { thousand) }\end{array}$ & x34 Number of Counties \\
\hline
\end{tabular}

b) Data normality test. Researchers take different methods of correlation analysis when the data distribution is in line normal distribution or not in line normal distribution. So before correlation analysis, researchers need to test whether the data meets the normal distribution or not. The most intuitive way of testing whether the data is in accordance with the normal distribution is to use probability plots of P-P and Q-Q. Researchers have used SPSS software to do P-P probability plots and Q-Q probability plots for a total of 35 indicators selected, finding that these data not normally distributed. c) Spearman and Kendall's correlation analysis. Since the data distribution does not meet the normal conditions, so researchers use Spearman and Kendall correlation analysis to make correlation analysis between truck ownership in various regions and other indicators. SPSS analysis results are shown in Table 2.

TABLE II. CORRELATION COEFFICIENT (CORRELATION IS SIGNIFICANT AT THE 0.01 LEVEL (2-TAILED).

\begin{tabular}{|c|c|c|}
\hline & Kendall's taub & Spearman's rho \\
\hline \multirow{2}{*}{ x1 } & 0.501 & 0.722 \\
\hline & 0.000 & 0.000 \\
\hline \multirow{2}{*}{$\mathrm{X} 2$} & 0.596 & 0.796 \\
\hline & 0.000 & 0.000 \\
\hline \multirow{2}{*}{$\mathrm{X} 3$} & 0.609 & 0.814 \\
\hline & 0.000 & 0.000 \\
\hline \multirow{2}{*}{$\mathrm{x} 4$} & 0.806 & 0.941 \\
\hline & 0.000 & 0.000 \\
\hline \multirow{2}{*}{ x5 } & 0.746 & 0.905 \\
\hline & 0.000 & 0.000 \\
\hline \multirow{2}{*}{ x6 } & 0.708 & 0.861 \\
\hline & 0.000 & 0.000 \\
\hline \multirow{2}{*}{$\mathrm{x} 7$} & 0.669 & 0.829 \\
\hline & 0.000 & 0.000 \\
\hline \multirow{2}{*}{ x8 } & 0.699 & 0.862 \\
\hline & 0.000 & 0.000 \\
\hline \multirow{2}{*}{ x9 } & 0.634 & 0.798 \\
\hline & 0.000 & 0.000 \\
\hline \multirow{2}{*}{$\mathrm{x} 10$} & 0.763 & 0.890 \\
\hline & 0.000 & 0.000 \\
\hline \multirow{2}{*}{ x11 } & 0.733 & 0.869 \\
\hline & 0.000 & 0.000 \\
\hline \multirow{2}{*}{$\mathrm{x} 12$} & 0.708 & 0.866 \\
\hline & 0.000 & 0.000 \\
\hline \multirow{2}{*}{$\mathrm{x} 13$} & 0.643 & 0.814 \\
\hline & 0.000 & 0.000 \\
\hline \multirow{2}{*}{$\mathrm{x} 14$} & 0.191 & 0.258 \\
\hline & 0.130 & 0.160 \\
\hline \multirow{2}{*}{$\mathrm{x} 15$} & 0.613 & 0.777 \\
\hline & 0.000 & 0.000 \\
\hline \multirow{2}{*}{ x16 } & 0.303 & 0.414 \\
\hline & 0.017 & 0.021 \\
\hline \multirow{2}{*}{$\mathrm{x} 17$} & 0.570 & 0.760 \\
\hline & 0.000 & 0.000 \\
\hline
\end{tabular}




\begin{tabular}{|c|c|c|}
\hline x18 & $\begin{array}{l}0.581 \\
0.000\end{array}$ & $\begin{array}{l}0.748 \\
0.000\end{array}$ \\
\hline x19 & $\begin{array}{l}0.394 \\
0.002\end{array}$ & $\begin{array}{l}0.572 \\
0.001\end{array}$ \\
\hline x 20 & $\begin{array}{l}0.673 \\
0.000\end{array}$ & $\begin{array}{l}0.834 \\
0.000\end{array}$ \\
\hline x21 & $\begin{array}{l}0.138 \\
0.294\end{array}$ & $\begin{array}{l}0.208 \\
0.279\end{array}$ \\
\hline $\mathrm{x} 22$ & $\begin{array}{l}0.600 \\
0.000\end{array}$ & $\begin{array}{l}0.760 \\
0.000\end{array}$ \\
\hline $\mathrm{x} 23$ & $\begin{array}{l}0.488 \\
0.000\end{array}$ & $\begin{array}{l}0.644 \\
0.000\end{array}$ \\
\hline x24 & $\begin{array}{l}0.256 \\
0.043\end{array}$ & $\begin{array}{l}0.368 \\
0.042\end{array}$ \\
\hline $\mathrm{x} 25$ & $\begin{array}{l}0.480 \\
0.000\end{array}$ & $\begin{array}{l}0.655 \\
0.000\end{array}$ \\
\hline x26 & $\begin{array}{l}0.523 \\
0.000\end{array}$ & $\begin{array}{l}0.706 \\
0.000\end{array}$ \\
\hline x27 & $\begin{array}{l}0.385 \\
0.002\end{array}$ & $\begin{array}{l}0.555 \\
0.001\end{array}$ \\
\hline $\mathrm{x} 28$ & $\begin{array}{l}0.652 \\
0.000\end{array}$ & $\begin{array}{l}0.807 \\
0.000\end{array}$ \\
\hline x29 & $\begin{array}{l}0.604 \\
0.000\end{array}$ & $\begin{array}{l}0.775 \\
0.000\end{array}$ \\
\hline x30 & $\begin{array}{l}0.630 \\
0.000\end{array}$ & $\begin{array}{l}0.824 \\
0.000\end{array}$ \\
\hline x31 & $\begin{array}{l}0.677 \\
0.000\end{array}$ & $\begin{array}{l}0.837 \\
0.000\end{array}$ \\
\hline x32 & $\begin{array}{l}0.643 \\
0.000\end{array}$ & $\begin{array}{l}0.801 \\
0.000\end{array}$ \\
\hline x33 & $\begin{array}{l}0.518 \\
0.000\end{array}$ & $\begin{array}{l}0.667 \\
0.000\end{array}$ \\
\hline x34 & $\begin{array}{l}0.535 \\
0.000\end{array}$ & $\begin{array}{l}0.747 \\
0.000\end{array}$ \\
\hline
\end{tabular}

From correlation analysis performed above, it is can be seen that main factors that affect China's truck ownership include China's total mileage, gross regional product in primary, secondary and tertiary industries, investment of infrastructure, new investment in fixed assets, total retail sales of consumer goods retail and so on . And it is substantially the same with the factors that influence truck ownership in this article earlier.
With the use of Spss17.0, researchers have made multiple regression analysis on normalized cross-sectional data and used stepwise regression method. According to significant level in which Sig is introduced as variables or on the basis of exclusive models, when Sig is less than or equal to 0.05 , the variable is introduced into the regression equation; when Sig is more than or equal 0.10 , the variable is removed from regression equation. Researchers get SPSS17.0's output in Table 3.

TABLE III. MODEL SUMMARY

\begin{tabular}{|c|l|l|l|l|}
\hline Model & \multicolumn{1}{|c|}{$\mathbf{R}$} & R Square & $\begin{array}{l}\text { Adjusted } \\
\text { R Square }\end{array}$ & $\begin{array}{l}\text { Std. Error of } \\
\text { the Estimate }\end{array}$ \\
\hline 1 & $.917(\mathrm{a})$ & .841 & .835 & .42048628 \\
2 & $.960(\mathrm{~b})$ & .922 & .915 & .30113300 \\
3 & $.994(\mathrm{c})$ & .989 & .986 & .25926702 \\
\hline
\end{tabular}

As can be seen from the summary of the fitting process above, three independent variables are introduced in the multiple regression fit, namely, resident consumption spending (hundred million RMB), cargo (ten thousand tons), total fixed asset investment (one trillion RMB).With the increase of number of independent variables, correction goodness of fit is increased from 0.835 up to 0.986 .

\section{ANALYSIS ON CHINA’s TRUCK MARKET}

From the analysis above, three independent variables are introduced in China's truck market holdings, namely, cargo, resident consumer spending and total fixed asset investment, so multiple linear regression model of China's truck market can be built.

$$
\mathrm{Y}=\beta 0+\beta 1 \times 1+\beta 2 \times 2+\beta 3 \times 3+\varepsilon
$$

In which: $Y$ is laden car ownership; $\beta 0, \beta 1, \beta 2, \beta 3$ are constants; $\mathrm{x} 1$ is cargo; $\mathrm{x} 2$ is resident consumer spending; $\mathrm{x} 3$ is total fixed asset investment; $\varepsilon$ is random error.

Relevant data obtained from China Statistical Yearbook can be seen in Table 4. 
TABLE IV. TABLE4. RELEVANT DATA IN CHINA'S TRUCK MARKET

\begin{tabular}{|c|c|c|c|c|}
\hline year & $\begin{array}{c}\text { Laden } \\
\text { car } \\
\text { ownershi } \\
\text { p (ten } \\
\text { thousand } \\
\text { ) }\end{array}$ & $\begin{array}{c}\text { Cargo } \\
\text { (hundred } \\
\text { million } \\
\text { tons) }\end{array}$ & $\begin{array}{c}\text { Resident } \\
\text { consumer } \\
\text { spending } \\
\text { (hundred } \\
\text { billion } \\
\text { Yuan) }\end{array}$ & $\begin{array}{c}\text { Total } \\
\text { fixed } \\
\text { asset } \\
\text { investme } \\
\text { nt } \\
\text { (trillion) }\end{array}$ \\
\hline 1995 & 131.83 & 123.49 & 28.36 & 6.297 \\
\hline 1996 & 142.78 & 129.84 & 33.95 & 7.518 \\
\hline 1997 & 163.19 & 127.82 & 36.92 & 8.176 \\
\hline 1998 & 192.03 & 126.74 & 39.22 & 9.044 \\
\hline 1999 & 228.68 & 129.30 & 41.92 & 9.618 \\
\hline 2000 & 259.09 & 135.87 & 45.85 & 10.21 \\
\hline 2001 & 298.95 & 140.18 & 49.43 & 11.83 \\
\hline 2002 & 341.29 & 148.34 & 53.05 & 13.53 \\
\hline 2003 & 367.35 & 156.45 & 57.64 & 16.33 \\
\hline 2004 & 402.81 & 170.64 & 65.21 & 21.22 \\
\hline 2005 & 452.10 & 186.20 & 72.95 & 27.09 \\
\hline 2006 & 494.91 & 203.70 & 82.57 & 32.62 \\
\hline 2007 & 539.44 & 227.58 & 96.33 & 39.64 \\
\hline 2008 & 596.39 & 258.59 & 111.67 & 49.84 \\
\hline 2009 & 753.40 & 282.52 & 123.58 & 64.70 \\
\hline 2010 & 931.51 & 324.18 & 140.75 & 77.73 \\
\hline 2011 & 1067.43 & 369.69 & 168.95 & 94.46 \\
\hline 2012 & 1175.63 & 409.94 & 190.42 & 113.59 \\
\hline
\end{tabular}

With the use of linear regression functions Spss17.0, results are shown in Table 5, Table 6, Table 7, and Table 8.

TABLE V. MODEL SUMMARY

\begin{tabular}{|l|l|l|l|l|}
\hline Model & R & R Square & Square & Estimate \\
\hline 1 & $.994 \mathrm{a}$ & .989 & .986 & 37.11081 \\
\hline
\end{tabular}

TABLE VI. ANOVAB

\begin{tabular}{|c|c|c|c|c|c|}
\hline & Model & Sum of Squares & df & $\mathbf{F}$ & Sig. \\
\hline 1 & Regression & 1706693.206 & 3 & 413.079 & $.000 \mathrm{a}$ \\
\hline & Residual & 19280.975 & 14 & & \\
\hline & Total & 1725974.182 & 17 & & \\
\hline
\end{tabular}

TABLE VII. COEFFICIENTS

\begin{tabular}{|c|c|c|c|c|c|}
\hline \multirow[b]{2}{*}{ Model } & \multicolumn{2}{|c|}{$\begin{array}{c}\text { Unstandardized } \\
\text { Coefficients }\end{array}$} & $\begin{array}{c}\text { Standardi } \\
\text { zed } \\
\text { Coefficien } \\
\text { ts }\end{array}$ & & \\
\hline & $B$ & $\begin{array}{l}\text { Std. } \\
\text { Error }\end{array}$ & Beta & $\mathbf{t}$ & Sig. \\
\hline $\begin{array}{l}1 \text { (Consta } \\
\text { nt) }\end{array}$ & 151.834 & 216.420 & & .702 & .494 \\
\hline $\mathrm{C}$ & 2.269 & 2.485 & .643 & .913 & .377 \\
\hline $\mathrm{R}$ & 8.217 & 2.683 & 1.256 & 3.063 & .008 \\
\hline $\mathrm{T}$ & 3.693 & 4.489 & .382 & .823 & .425 \\
\hline
\end{tabular}

TABLE VIII. COLLINEARITY DIAGNOSTICS

\begin{tabular}{|c|c|c|c|c|c|c|c|}
\hline \multirow[b]{2}{*}{$\begin{array}{c}\text { Mod } \\
\text { el }\end{array}$} & \multirow[b]{2}{*}{$\begin{array}{c}\text { Dime nsio } \\
\mathbf{n}\end{array}$} & \multirow{2}{*}{$\begin{array}{c}\text { Eige } \\
\text { nval } \\
\text { ue }\end{array}$} & \multirow[b]{2}{*}{$\begin{array}{c}\text { Conditio } \\
\text { n Index }\end{array}$} & \multicolumn{4}{|c|}{ Variance Proportions } \\
\hline & & & & $\begin{array}{c}\text { (Constant } \\
\text { ) }\end{array}$ & $C$ & $R$ & $T$ \\
\hline 1 & 1 & 3.712 & 1.000 & .00 & .00 & .00 & .00 \\
\hline & 2 & .286 & 3.600 & .00 & .00 & .00 & .00 \\
\hline & 3 & .002 & 44.340 & .05 & .00 & .40 & .30 \\
\hline & 4 & .000 & 141.720 & .94 & 1.00 & .60 & .69 \\
\hline
\end{tabular}

In Table: $\mathrm{C}$ is cargo; $\mathrm{R}$ is resident consumer spending; $\mathrm{T}$ is total fixed asset investment

From Table 5, researchers can see that goodness of fit has reached $98.9 \%$, so researchers can have a positive attitude towards the regression model. From significant $\mathrm{P}$ value sig. $=0.000$ (approx.) in Table 6, researchers can know that the regression equation is very significant. That is to say, from the probability of more than $99.9 \%$, researchers confirm that all independent variables of $\mathrm{x} 1$, $\mathrm{x} 2$ and $\mathrm{x} 3$ have significant influence on the dependent variable of Y. Therefore, from Table 7, the regression equation is:

\section{$\mathrm{Y}=151.834+2.269 \times 1+8.217 \times 2+3.693 \times 3$}

$\mathrm{Y}$ is laden vehicle ownership (ten thousand); $\mathrm{x} 1$ is cargo (billion); $\mathrm{x} 2$ is resident consumer spending (one hundred billion Yuan); $\mathrm{x} 3$ is total fixed asset investment (one trillion Yuan).

In the meanwhile, the results in Table 7 show that the model also passed the T-test. 


\section{CONCLUSIONS}

From the results of the application, the regression model can be used to analyze and forecast China's truck market.

\section{A. Economic sense}

From variable symbols of the model, with the increase of consumer spending, freight and total fixed assets investment, China's truck market holdings also increase, and this is of real economic significance. It can be understood that, the increase of the resident consumer spending would inevitably stimulate production of goods and goods transport. The increase in fixed assets will inevitably lead to increased investment in construction projects and construction. All of these will lead to increased road transport and inevitable need for more trucks. Therefore, truck ownership is bound to rise.

\section{B. Statistical Test}

In the process of the construction of the model, researchers have tested goodness of fit, $f$ value and $t$ value. Equations have been passed the test, so researchers don't mention this here any longer.

\section{Multicollinearity}

With the use of SPSS and contrast expansion factor, output can be seen that the tolerance of several independent variables is greater than 0.1.Therefore the model is judged that no multicollinearity exists here.

In short, the model has been passed the test of heteroscedasticity and correlation, and the model is reasonable in the economic sense. Therefore, researchers think that this model is a good regression model, which can be applied to the analysis and forecasting of China's truck market.

\section{REFERENCES}

[1] Megersa Abate;Gerard de Jong. The optimal shipment size and truck size choice - The allocation of trucks across hauls [J]. Transportation Research. Part A, Policy and Practice. 2014, (59): 262-277.

[2] Samsul Islam; Tava Olsen. Truck-sharing challenges for hinterland trucking companies: A case of the empty container truck trips problem $[\mathrm{J}]$.Business Process Management Journal. 2014, 20(2): 290-313.

[3] C. K. Kwong,H. Bai. A fuzzy AHP approach to the determination of importance weights of customer requirements in quality function deployment $[\mathrm{J}]$. Journal of Intelligent Manufacturing. 2002 (5) 17-29

[4] Lixin Tang;Jiao Zhao; Jiyin Liu. Modeling and solution of the joint quay crane and truck scheduling problem [J]. European Journal of Operational Research. 2014, 236(3):978-990.
[5] Morton, C.; Pickert, V.; Armstrong, M. Self-Alignment Torque as a Source of Energy Recovery for Hybrid Electric Trucks[J]. Vehicular Technology, IEEE Transactions on. 2014, 63(1):62-71.

[6] Christine Lambert; Douglas Dobson;Christine Gierczak; Gang Guo;Justin Ura;James Warner. Nitrous oxide emissions from a medium-duty diesel truck exhaust system[J]. International Journal of Powertrains. 2014, 3(1):4-25.

[7] Torrey, S.;Bergeron, R.; Widowski, T.;Lewis, N.;Crowe, T.; Correa, J. A.; Brown, J.;Gonyou, H. W.; Faucitano, L. Transportation of market-weight pigs: Effect of season, truck type, and location within truck on behavior with a two-hour transport[J]. Journal of Animal Science. 2013, 91(6):2863-2871.

[8] Shih-Wen Hsiao.Concurrent design method for developing a new product [J]. International Journal of Industrial Ergonomics . 2002 (1) $34-49$

[9] Jana Sochor; Gideon Mbiydzenyuy. Assessing the Benefits of Intelligent Truck Parking [J]. International Journal of Intelligent Transportation Systems Research. 2013, 11(2):43-53.

[10] Phillip McCalman; Alan Spearot. Why trucks jump: Offshoring and product characteristics [J]. Journal of International Economics. 2013, 91(1):82-95.

[11] Costello, Bob. The Trucking Industry: The Lynchpin of the U.S. Economy $[\mathrm{J}]$. Business economics: the Journal of the National Association. 2013, 48(3):195-201.

[12] Christopher B. Clott; Bruce C. Hartman. Clean trucks in California ports: Modeling emissions policy $[\mathrm{J}]$. International Journal of Shipping and Transport Logistics. 2013, 5(4-5):449-462.

[13] Ryan, Michael. Garbage Truck [J]. The American Poetry Review. 2012, 41(1):48-52

[14] Lundin, Johan F.; Hedberg, Leyla. A Comparison of Contract Types for Procuring Trucking Services: A Case Study of A Large Swedish Retailer [J]. Transportation Journal. 2012, 51(2):238-255.

[15] Yannick Ferreira De Sousa;Alistair Munro. Truck, barter and exchange versus the endowment effect: Virtual field experiments in an online game environment $[\mathrm{J}]$. Journal of Economic Psychology. 2012, 33(3):482-493.

[16] Christer LJUNGWALL,Zijian WANG. Why is capital flowing out of China?[J]. China Economic Review. 2007 (3) 61

[17] Renhai Hua,Baizhu Chen. International linkages of the Chinese futures markets [J]. Applied Financial Economics. 2007 (16)44-49

[18] Marina Marinelli; Sergios Lambropoulos; John-Paris Pantouvakis. Investigation of earthmoving trucks deterioration using discriminant analysis $[\mathrm{J}]$. International Journal of Project Organization and Management. 2012, 4(4):397-413

[19] Christian N. Madu,Chuhua Kuei,Ifeanyi E. Madu.A hierarchic metric approach for integration of green issues in manufacturing: a paper recycling application[J].Journal of Environmental Management . 2002 (3) 23-38

[20] Lee J, Cho J., 2005. Consumers' use of information intermediaries and the impact on their information search behavior in the financial market $[\mathrm{J}]$. The Journal of Consumer Affairs, 39 (1): 95-120.

[21] Randy Brenkers, Frank Verboven, 2006. Liberalizing a distribution system: the European car market[J]. Journal of European Economic Association, 1:216-251.

[22] Strebel J, Erdem T, Swait J., 2004. Consumer search in high technology markets: exploring the use of traditional information channels [J]. Journal of Consumer Ps ychology, 14(1, 2): 96-104.

[23] Roger R. Betancourt; Raquel Chocarro;Monica Cortinas; Margarita Elorz;Jose Miguel Mugica. The Impact of Market Environments on Marketing Relationships [J]. International Journal of Marketing Studies. 2014, 6(1):45-71.

[24] Zhaowei Miao;Shun Cai;Di Xu. Applying an adaptive tabu search algorithm to optimize truck-dock assignment in the crossdock management system [J]. Expert Systems with Applications. 2014, 41(1):16-22. 